\title{
The paraoxonase 1 activity and lipid levels in umbilical cord blood and maternal venous blood, and their relations according to birth weight
}

\author{
Berrin Göktuğ Kadıŏ̆lu, Aysel Nalçakan²®, Esra Dilek ${ }^{3} \odot$ \\ ${ }^{1}$ Department of Obstetrics and Gynecology, University of Health Sciences, Erzurum Regional Training and Research Hospital, Erzurum, \\ Turkey \\ ${ }^{2}$ Department of Obstetrics and Gynecology, Pursaklar State Hospital, Ankara, Turkey \\ ${ }^{3}$ Department of Basic Pharmaceutical Science, Erzincan Binali Ylldirım University, Faculty of Pharmacy, Erzincan, Turkey
}

\section{ABSTRACT}

Objectives: Aim of this study is to find out the clinical relevance of estimating paraoxonase activity of PON1 enzyme, triglyceride (TG), total cholesterol, HDL, and LDL levels in maternal serum and umbilical cord blood according to birth weight.

Methods: Venous blood samples were taken from mothers just before birth. Babies were divided into four groups: normal-weight babies, premature babies, low birth weight babies, and postmature babies. The weight of the newborns was measured and cord blood was taken. The samples were looked at HDL, LDL, total cholesterol, triglyceride levels and PON1 activities. We have investigated the paraoxonase activity of the PON1 enzyme. Enzyme activity assay was obtained spectrophotometrically measurement of p-nitrophenol at 412 $\mathrm{nm}$.

Results: Maternal PON1 paraoxonase activity levels in Pre-Term show a significant decrease in cases as compared to other groups. Baby PON1 paraoxonase activity levels are also found to be significantly decreased in cases concerning the Term and Post-Term groups. There was a significant difference in all values the such as baby's weight, TG, Total cholesterol, HDL, LDL and PON1.belonging to babies $(p<0.05)$.

Conclusions: Decreased paraoxonase activity in maternal serum may be considered as an additional risk factor for the development of low birth weight. It appears that PON1 activity plays an important role in infant development and affects birth weight. We think that the paraoxonase activity of the PON1 enzyme in mothers may be a marker in predicting the babies who are at risk in terms of birth weight.

Keywords: Birth weight, paraoxonase 1 enzyme, lipid levels, maternal serum, baby cord blood

$I^{\prime}$

$t$ is known that many factors affect the birth weight of the baby during pregnancy. Some of those are many anatomical, genetic, metabolic, endocrine causes such as nutritional disorders, low mother weight, chromosomal disorders, cigarette-alcohol consumption, gestational diabetes, hypertension, placental anomalies, drug use, cord anomalies, oligohydram- nios. These causes negatively affect the development of the baby [1]. Various studies show that systemic and placental oxidative stress is also effective in this by making placental dysfunction [2]. Diseases associated with oxidative stress particularly affect newborns with low birth weight [3]. Low birth weight has been defined by the World Health Organization (WHO) as 
weight at birth of less than $2500 \mathrm{~g}(5.5 \mathrm{lb})$ [4]. Oxidative reactions occur with reactive oxygen radicals that will damage cells in the organism, and antioxidant mechanisms protect cells from this damage [5]. Many enzymes in the body have antioxidant effects. One of these is the Paraoxonase (PON) enzyme [6]. PON is a calcium-dependent ester hydrolase enzyme that is carried in the HDL structure in the blood and has high antioxidant effects. Mammals have three different PON genes (PON1, PON2 and PON3) on the same chromosome $[7,8]$. PON1 is an enzyme with paraoxonase, arylesterase and lactonase activities that can react with a wide variety of substrates [9]. PON 1 can hydrolyze aryl and alkyl halides and organophosphates. It is synthesized in the liver and introduced into the bloodstream. PON1 protects both HDL and LDL from oxidation and can neutralize radicals [10]. Increased LDL oxidation in the serum creates endothelial damage and causes the formation of atheroma plaques. HDL dependent PON1 prevents this effect with its antioxidant feature. PON1 activity has been found to be low in people with potential risk for atherosclerosis such as diabetes, familial hypercholesterolemia, slow coronary flow $[11,12]$. PON1 activity in newborns and premature babies is about half that in adults [13]. In a study, it was reported that maternal obesity increased susceptibility to oxidative damage in mother and newborn, and there was a decrease in PON-1 activity in both mother blood and cord blood [14]. Just as in the coronary arteries, studies are investigating the presence of plaque-disrupting plaques in placental vessels and their effect on fetal weight $[15,16]$.

This study aims to determine the relationship between lipid profile and PON1 enzyme activity in maternal venous blood and umbilical cord blood with birth weight, and to investigate whether this enzyme can be a marker for predicting babies at risk for birth weight.

\section{METHODS}

\section{Patients/Volunteers and Ethics Statement}

Eighty pregnant women who were hospitalized at Nenehatun Maternity Hospital (Erzurum-Turkey) and their newborn babies were included in our study. Twenty premature babies (among those born before 37th gestational week), 20 low birth weight babies (among those born at term but below 2500 grams), 20 normal-weight babies (among babies born at term), 20 postmature babies (among those born after 41 st gestational week) was evaluated. Pregnant women between 18-40 years of age who had pregnancy follow-ups, without any chronic disease, no visualhearing and communication disabilities, volunteering to participate in the study and signed the consent form were included in this study. In addition, cases with preeclampsia, gestational diabetes mellitus, intrauterine growth retardation and premature rupture of membranes were not included in the study. Babies with asphyxia, babies with respiratory distress syndrome, babies with severe anomaly and cardiac disease, babies with chorioamnionitis and infection in their mother, babies with the metabolic disease were excluded from the study.

The weight of mothers was measured just before birth, and venous blood samples were taken. Babies were divided into four groups: normal-weight babies (Group 1: Term), premature babies (Group 2: PreTerm), low birth weight babies (Group 3: small for gestational age [SGA]), and postmature babies (Group 4: Post-Term). The weight of the newborns was measured and cord blood was taken. The samples were looked at HDL, LDL, total cholesterol, triglyceride levels and PON1 activities. Samples were taken into a straight biochemistry tube. The samples which will be measured PON1 activity was taken into the biochemistry tube, then centrifuged for 10 minutes at $4000 \mathrm{rpm}$, After centrifuged, their serum was separated and kept in the freezer at $-20 \mathrm{oC}$ until the day of analysis.

This study was approved by the Clinical Researches of Ethical Committee of the Ataturk University (Erzurum-Turkey) (confirmation code: B.30.2.ATA.0.01.00/391).

\section{Materials}

Protein assay reagents, 4-nitrophenylacetate were purchased from Sigma-Aldrich Co. All other chemicals were analytical grade and obtained from Merck. Mother's venous blood samples and umbilical cord blood samples were taken from the Department of Obstetrics and Gynecology at a maternity hospital.

\section{Serum Lipid Levels}

In serum, lipid profile was evaluated with Cobas 6000- 
501 module auto analyzer (Roche) by the photometric method.

\section{PON1 Activity Assay}

The whole PON1 activity procedure was performed according to our previous studies $[10,17]$. Briefly, Paraoxonase activity of PON1 has been investigated with paraoxone $(1 \mathrm{mM})$ in $50 \mathrm{mM}$ glycine$\mathrm{NaOH}(\mathrm{pH} 10.5)$ buffer including $1 \mathrm{mM} \mathrm{CaCl} 2$ at $25^{\circ} \mathrm{C}$. Enzyme activity assay is based on spectrophotometric measurement of $\mathrm{p}$-nitrophenol at $412 \mathrm{~nm}$. The molar extinction coefficient of paranitrophenol $(\varepsilon$ $=18.290 \mathrm{M}-1 \mathrm{~cm}-1$ at $\mathrm{pH} 10.5)$ is used for the calculation of the activity. One enzyme unit was defined as the amount of enzyme that catalyzes the hydrolysis of $1 \mu \mathrm{mol}$ of paraoxon at $25^{\circ} \mathrm{C}$.

\section{Protein Determination}

To calculate the specific activity of the PON1 enzyme, protein assay was performed spectrophotometrically at $595 \mathrm{~nm}$ according to the Bradford method, using bovine serum albumin as the standard $[10,17]$.

\section{Statistical Analysis}

SPSS 23.0 software was used for statistical calculations. Descriptive statistics (mean, standard devia- tion, median, minimum and maximum values) were given for numerical variables while evaluating the data. In the study, the differences or relationships of other variables were examined according to the diagnostic variable. A cross table was created as a method for categorical variables and the Chi-Square test was applied. Kruskal-Wallis Test was used as a method for numerical variables. The purpose of the Kruskal-Wallis Test (sometimes also called the "one-way ANOVA on ranks") is to test the differences between three or more groups in groups that do not show normal distribution. When the data are examined, the diagnosis variable consists of four groups. The Kruskal-Wallis Test was used to examine whether there was a statistically significant difference between the groups in terms of variables. Statistical significance was taken as 0.05 in the analysis.

\section{RESULTS}

The analysis process of the research data has been examined under three headings. First, the distribution of variables and descriptive statistics are given. In the second stage, the relationship between gender, which is a categorical variable, and the diagnosis was given

Table 1. Descriptive statistics by groups

\begin{tabular}{lccccc}
\hline & $\begin{array}{c}\text { Post-Term } \\
(\mathbf{n}=\mathbf{2 0})\end{array}$ & $\begin{array}{c}\text { Term } \\
(\mathbf{n}=\mathbf{2 0})\end{array}$ & $\begin{array}{c}\text { Pre-Term } \\
(\mathbf{n}=\mathbf{2 0})\end{array}$ & $\begin{array}{c}\text { SGA } \\
(\mathbf{n}=\mathbf{2 0})\end{array}$ & $p$ value \\
\hline Mean \pm SEM & Mean \pm SEM & Mean \pm SEM & Mean \pm SEM & \\
Age & $25.10 \pm 4.930$ & $27.45 \pm 5.763$ & $26.05 \pm 4.407$ & $25.30 \pm 5.713$ & 0.373 \\
Gravida & $2.10 \pm 1.553$ & $2.55 \pm 1.701$ & $2.95 \pm 2.012$ & $2.05 \pm 1.877$ & 0.202 \\
Parity & $2.38 \pm 1.188$ & $2.33 \pm 1.497$ & $1.79 \pm 1.188$ & $2.00 \pm 1.309$ & 0.498 \\
\hline
\end{tabular}

$\mathrm{SGA}=$ small for gestational age, $\mathrm{SEM}=$ standard error of mean

Table 2. Examination of the relationship between infant gender and diagnosis variable

\begin{tabular}{|c|c|c|c|c|c|c|c|c|c|}
\hline & & & Post-Term & Term & Pre-Term & SAG & Total & $\begin{array}{l}\text { Chi- } \\
\text { Square }\end{array}$ & $\begin{array}{c}p \\
\text { value }\end{array}$ \\
\hline \multirow[t]{4}{*}{ Baby's Gender } & Girl & Number & 8 & 12 & 9 & 13 & 42 & 3.409 & 0.333 \\
\hline & & Percent & 19.0 & 28.6 & 21.4 & 31.0 & 100.0 & & \\
\hline & Boy & Number & 12 & 8 & 11 & 7 & 38 & & \\
\hline & & Percent & 31.6 & 21.1 & 28.9 & 18.4 & 100.0 & & \\
\hline \multirow[t]{2}{*}{ Total } & & Number & 20 & 20 & 20 & 20 & 80 & & \\
\hline & & Percent & 25.0 & 25.0 & 25.0 & 25.0 & 100.0 & & \\
\hline
\end{tabular}


by cross-tables method and chi-square test. In the third stage, the Kruskal-Wallis Test was used to examine whether there was a significant difference between numerical variables according to diagnoses.

\section{Descriptive Statistics}

Participants $(n=80)$ are presented in Table 1 with their mean values and standard deviations.

\section{Cross Table Method and Chi-Square Analysis}

Table 2 shows whether there is a dependent relationship between gender and the diagnosis variable. At the same time, the frequent values and percentage values in the diagnosis variable of the sexes were also shown.

When the chi-square test is examined, we can say that there is no statistically significant relationship between gender and diagnosis $(p>0.05)$.

Table 3 prensents whether there is a difference between the diagnosis variable and t variables. KruskalWallis Test result values and $p$ values were also given along with the median, minimum and maximum values of the variables. The p-values have been evaluated to decide whether there is a statistically significant difference.

According to our results, there was no statistically significant difference between maternal values except PON1 paraoxonase activity levels $(p>0.05)$. These values are maternal's age, gravida, parite, TG, Total cholesterol, HDL and LDL. There was a statistically significant difference in all values belonging to babies $(p<0.05)$. These values are the baby's weight, TG, Total cholesterol, HDL, LDL and PON1.

The maternal PON1 level of the Pre-Term was significantly lower than the Term, Post-Term, and SGA groups. In addition, maternal PON 1 level of Term group is significantly higher than SGA group.

The baby weight of the Pre-Term and SGA groups was significantly less than the Term and Post-Term groups.

The Total cholesterol level of the Pre-Term group was significantly higher than the Post-Term and SGA groups. The TG level of the SGA group was significantly higher than the Term and Pre-Term groups. The HDL level of the Pre-Term group was significantly higher than the Post-Term and SGA groups. The LDL level of the Pre-Term group was significantly higher than the Post-Term and SGA groups.
The baby PON1 level of the Pre-Term and SGA groups was significantly lower than the Term and Post-Term groups.

\section{DISCUSSION}

The weight of the newborn is affected by many factors such as the mother's nutrition, socio-economic status, diseases, environmental conditions and genetics. It is directly related to the adaptation of the baby to the external environment. For this reason, it is very important that the baby is born at the optimum weight [1]. Various studies are showing the relationship between maternal weight and lipid profile with newborn weight. In the study of Ouidir et al. [18], it was reported that maternal lipids affect fetal development. In a study by Brittos et al. [19], it was reported that there was a relationship between maternal weight, newborn weight and lipids in the umbilical cord blood. Kim et al. [20] conducted a study on the effect of oxidative stress on birth weight in pregnant women. They reported that the levels of malondialdehyde, one of the main products of lipid peroxidation and an indicator of the oxidant-antioxidant balance of the placenta, in maternal urine were high, and the birth weight of the babies of these mothers was low. It has been reported that maternal oxidative stress may affect birth weight in this study [20]. Negi et al. [21] conducted a study on the evaluation of biomarkers of oxidative stress and antioxidant capacity in cord blood of preterm newborns with low birth weight. In this study, it was reported that oxidative stress was high especially in babies born with low birth weight, and morbidity and mortality increased in these babies. Oxidative stress is also higher in newborn babies, as antioxidant defense mechanisms are not fully mature and oxidant loads are high [21]. In another study by Negi et al. [3], they found a significant increase in malondialdehyde and 8-Hydroxy-2-deoxy guanosine (one of the markers of oxidative DNA damage) levels in premature babies with low birth weight. It has been reported that the weight of the newborn baby is important in terms of oxidative stress, morbidity and mortality [3]. In our study, we determined the PON1 enzyme activity as an antioxidant. This enzyme is half the size of the newborn in the adult human and rises to the adult level one year after birth and remains con- 
Table 3. Examination of the difference between variables based on diagnoses

\begin{tabular}{|c|c|c|c|c|c|c|}
\hline & & Median & Minimum & Maximum & K.W. & $p$ value \\
\hline \multirow[t]{4}{*}{ Maternal TG } & 1) POST-TERM & 250.00 & 60.00 & 376.00 & 6.185 & 0.103 \\
\hline & 2) TERM & 194.50 & 118.00 & 406.00 & & \\
\hline & 3) PRE-TERM & 223.00 & 122.00 & 268.00 & & \\
\hline & 4) SGA & 276.50 & 102.00 & 357.00 & & \\
\hline \multirow[t]{4}{*}{ Maternal Total Cholesterol } & 1) POST-TERM & 276.00 & 51.00 & 398.00 & 4.719 & 0.194 \\
\hline & 2) TERM & 277.00 & 187.00 & 398.00 & & \\
\hline & 3) PRE-TERM & 253.50 & 147.00 & 525.00 & & \\
\hline & 4) SGA & 218.00 & 178.00 & 381.00 & & \\
\hline \multirow[t]{4}{*}{ Maternal HDL } & 1) POST-TERM & 68.00 & 23.00 & 98.00 & 6.915 & 0.075 \\
\hline & 2) TERM & 80.50 & 40.00 & 105.00 & & \\
\hline & 3) PRE-TERM & 74.00 & 38.00 & 125.00 & & \\
\hline & 4) SGA & 64.00 & 44.00 & 106.00 & & \\
\hline \multirow[t]{4}{*}{ Maternal LDL } & 1) POST-TERM & 134.50 & 16.00 & 272.00 & 3.739 & 0.291 \\
\hline & 2) TERM & 147.50 & 86.00 & 370.00 & & \\
\hline & 3) PRE-TERM & 147.50 & 66.00 & 300.00 & & \\
\hline & 4) SGA & 117.00 & 61.00 & 266.00 & & \\
\hline \multirow[t]{4}{*}{ Maternal PON1 } & 1) POST-TERM & 130.70 & 119.30 & 151.00 & 59.004 & $<0.001 *$ \\
\hline & 2) $\mathrm{TERM}^{\mathbf{b}}$ & 138.50 & 126.30 & 146.30 & & \\
\hline & 3) PRE-TERM & 103.60 & 95.20 & 107.80 & & \\
\hline & 4) $\mathrm{SGA}^{\mathrm{a}, \mathrm{b}}$ & 111.20 & 92.90 & 177.00 & & \\
\hline \multirow[t]{4}{*}{ Baby Weight } & 1) POST-TERM ${ }^{\mathbf{b}, \mathbf{c}}$ & 3282.50 & 2700.00 & 3850.00 & 57.174 & $<0.001 *$ \\
\hline & 2) $\mathrm{TERM}^{\mathbf{b}, \mathbf{c}}$ & 2980.00 & 2605.00 & 3900.00 & & \\
\hline & 3) PRE-TERM & 2440.00 & 1800.00 & 2860.00 & & \\
\hline & 4) SGA & 2400.00 & 2200.00 & 2470.00 & & \\
\hline \multirow[t]{4}{*}{ Baby Total Cholesterol } & 1) POST-TERM & 52.00 & 37.00 & 80.00 & 15.776 & $0.001 *$ \\
\hline & 2) TERM & 63.00 & 38.00 & 268.00 & & \\
\hline & 3) PRE-TERM & 67.00 & 57.00 & 217.00 & & \\
\hline & 4) $\mathrm{SGA}^{\mathrm{b}}$ & 57.50 & 34.00 & 70.00 & & \\
\hline \multirow[t]{4}{*}{ Baby TG } & 1) POST-TERM & 32.50 & 23.00 & 88.00 & 14.788 & $0.002 *$ \\
\hline & 2) TERM $^{\mathbf{c}}$ & 32.00 & 17.00 & 242.00 & & \\
\hline & 3) PRE-TERM ${ }^{c}$ & 30.00 & 16.00 & 60.00 & & \\
\hline & 4) SGA & 50.50 & 22.00 & 82.00 & & \\
\hline \multirow[t]{4}{*}{ Baby HDL } & 1) POST-TERM ${ }^{\mathbf{b}}$ & 26.50 & 18.00 & 46.00 & 18.385 & $<0.001 *$ \\
\hline & 2) TERM & 28.00 & 18.00 & 108.00 & & \\
\hline & 3) PRE-TERM & 33.50 & 25.00 & 45.00 & & \\
\hline & 4) $\mathrm{SGA}^{\mathrm{b}}$ & 24.00 & 13.00 & 39.00 & & \\
\hline \multirow[t]{4}{*}{ Baby LDL } & 1) POST-TERM & 20.50 & 6.00 & 37.00 & 25.997 & $<0.001 *$ \\
\hline & 2) TERM & 25.50 & 7.00 & 112.00 & & \\
\hline & 3) PRE-TERM & 30.00 & 16.00 & 68.00 & & \\
\hline & 4) $\mathrm{SGA}^{\mathrm{b}}$ & 19.00 & 8.00 & 32.00 & & \\
\hline \multirow[t]{4}{*}{ Baby PON1 } & 1) POST-TERM ${ }^{\mathbf{b}, \mathbf{c}}$ & 52.60 & 43.80 & 55.70 & 58.310 & $<0.001 *$ \\
\hline & 2) $\mathrm{TERM}^{\mathbf{b}, \mathbf{c}}$ & 51.85 & 45.20 & 57.30 & & \\
\hline & 3) PRE-TERM & 37.80 & 31.80 & 44.70 & & \\
\hline & 4) SGA & 43.80 & 40.70 & 51.20 & & \\
\hline
\end{tabular}

K.W. $=$ Kruskal Wallis Analysis $* p<0.05$ (Statistically significant). Significance against TERM group, ${ }^{\mathrm{a}} p<0.05$; significance against PRE-TERM group, ${ }^{\mathbf{b}} p<0.05$; significance against SGA group, ${ }^{\mathbf{c}} p<0.05$. 
stant throughout life. It does not differ according to gender [13]. Therefore, we did not discriminate regarding the gender of the babies in our study. It has been reported that PON1 activity decreases in cases of increased oxidative stress such as dyslipidemia, diabetes mellitus, hypertension, advanced maternal age, and cigarette-alcohol consumption [22]. Ferretti et al. [14] evaluated leptin and PON1 activity in the cord blood of obese mothers. In this study, it was concluded that PON1 activity decreased in obese women compared to normal weight, and oxidative damage increased in mother and baby [14]. Mogarekar et al. [23] investigated the relationship between newborn birth weight and maternal serum PON1 arylesterase activity and found a positive correlation between them. And in their study, it was stated that this situation may be an additional risk factor in low birth weight babies [23].

Some researchers have explored the relationship between PON1 activity and pregnancy complications [24, 25]. Kumru et al. [25] have shown in their study that PON1 activity decreased in preeclamptic pregnancies. Lawlor et al. [24] indicated in their study that there is a close relationship between PON-1 Q192R polymorphism and preterm birth. Our study also supports these studies. We revealed that the paraoxonase activity of the PON1 enzyme in mothers affects both the gestational week and may be a marker in predicting the babies who are at risk in terms of birth weight.

\section{CONCLUSION}

To conclude, we can say that mothers with low paraoxonase activity of PON1 enzyme are more likely to deliver a baby with low birth weight. It appears that PON1 activity plays an important role in infant development and affects the birth weight of a newborn. Decreased paraoxonase activity in maternal serum may be considered as the additional risk factor for the development of low birth weight newborns. We think that the paraoxonase activity of the PON1 enzyme in mothers may be a marker in predicting the babies who are at risk in terms of birth weight.

\section{Authors' Contribution}

Study Conception: ED, BK; Study Design: ED, BK, AN; Supervision: ED, BK; Funding: ED, BK, AN; Materials: BK, AN; Data Collection and/or Pro- cessing: ED, BK, AN; Statistical Analysis and/or Data Interpretation: $\mathrm{ED}, \mathrm{BK}$; Literature Review: $\mathrm{ED}, \mathrm{BK}$, AN; Manuscript Preparation: ED, BK and Critical Review: ED.

\section{Conflict of interest}

The authors disclosed no conflict of interest during the preparation or publication of this manuscript.

\section{Financing}

The authors disclosed that they did not receive any grant during conduction or writing of this study.

\section{REFERENCES}

1. Sharma D, Sharma P, Shastri S. Genetic, metabolic and endocrine aspect of intrauterine growth restriction: an update. $\mathrm{J}$ Matern Fetal Neonatal Med 2017;30:2263-75.

2. Gupta S, Agarwal A, Banerjee J, Alvarez JG. The role of oxidative stress in spontaneous abortion and recurrent pregnancy loss: a systematic review. Obstet Gynecol Surv 2007;62:335-47. 3. Negi R, Pande D, Kumar A, Khanna RS, Khanna HD. In vivo oxidative DNA damage and lipid peroxidation as a biomarker of oxidative stress in preterm low-birthweight infants. J Trop Pediatr 2012;58:326-8.

4. World Health Organization. International statistical classification of diseases and related health problems. Tenth revision. Geneva: World Health Organization; 1992.

5. Halliwell B, Gutteridge JMC. Lipid peroxidation oxygen radicals. cell damage and antioxidant therapy. Lancet 1984;23:139697.

6. Islam MdO, Bacchetti T, Ferretti G. Alterations of antioxidant enzymes and biomarkers of nitro-oxidative stress in tissues of bladder cancer. Oxid Med Cell Longev 2019;2019:2730896.

7. Hegele RA. Paraoxonase genes and disease. Ann Med 1999;31:217-24.

8. Mackness MI, Halton SD, Pend T, Warner S, Walken CN. The seperation of sheep and human serum A-esterase activity with the lipoprotein fraction by ultracentrifugation. Biochem Physiol 1985;82:675-77.

9. Rodrigo L, Hernández AF, López-Caballero JJ, Gil F, Pla A. Immunohistochemical evidence for the expression and induction of paraoxonase in rat liver. kidney. lung and brain tissue. Implications for its physiological role. Chem Biol Interact 2001;137:123-37.

10. Yilmaz A, Dilek E. Antibiotics used in patients after surgery and effects of human serum paraoxonase-I (PON1) enzyme activity. Protein Pept Lett 2019;26:215-20.

11. Yildiz A, Sezen Y, Gur M, Yilmaz R, Demirbag R, Erel O. Association of paraoxonase activity and coronary collateral flow. Coron Artery Dis 2008;19:441-7.

12. Renault F, Chabrière E, Andrieu JP, Dublet B, Masson P, Rochu DJ. Tandem purification of two HDL-associated partner 
proteins in human plasma. paraoxonase (PON1) and phosphate binding protein (HPBP) using hydroxyapatite chromatography. J Chromatogr B 2006;836:15-21.

13. Mackness B, Durrington PN, Mackness M. Human serum paraoxonase. Gen Pharmac 1998;31:329-36.

14. Ferretti G, Cester AM, Bacchetti T, Raffaelli F, Vignini A, Orici $\mathrm{F}$, et al. Leptin and paraoxonase activity in cord blood from obese mothers. J Matern Fetal Neonatal Med 2014;27:1353-6.

15. Chen D, Hu Y, Chen C, Yang F, Fang Z, Wang L, et al. Polymorphisms of the paraoxonase gene and risk of preterm delivery. Epidemiology 2004;15:466-70.

16. Rotshenker-Olshinka K, Michaeli J, Srebnik N, Terlezky S, Schreiber L, Farkash R, et al. Recurrent intrauterine growth restriction: characteristic placental histopathological features and association with prenatal vascular Doppler. Arch Gynecol Obstet 2019;300:1583-9.

17. Dilek E, Çağlar S, Cardak S, Karakoc B, Çağlar B, Şahin O. Synthesis, characterization, and in vitro effect of the $\mathrm{Cu}$ (II) complex with niflumic acid and 3-picoline on paraoxanase-I. Archiv Der Pharmazie 2019;352:e1900007.

18. Ouidir M, Mendola P, Workalemahu T, Grewal J, Grantz KL, Zhang C, et al. Race-ethnic differences in the associations of maternal lipid trait genetic risk scores with longitudinal fetal growth. J Clin Lipidol 2019;13:821-31.

19. Brittos T, de Souza WB, Anschau F, Pellanda L. Lipids and leukocytes in newborn umbilical vein blood. birth weight and maternal body mass index. J Dev Orig Health Dis 2016;7:672-7. 20. Kim YJ, Hong YC, Lee KH, Park HJ, Park EA, Moon HS, et al. Oxidative stress in pregnant women and birth weight reduction. Reprod Toxicol 2005; 19:487-92.

21. Negi R, Pande D, Kumar A, Khanna RS, Khanna HD. Evaluation of biomarkers of oxidative stress and antioxidant capacity in the cord blood of preterm low birth weight neonates. J Matern Fetal Neonatal Med 2012;25:1338-41.

22. Senti M, Tomas M, Fito M. Antioxidant paraoxonase 1 activity in the metabolic syndrome. J Clin Endocrinol Metab 2003;88:5422-6.

23. Mogarekar MR, Dhabe MG, Gujrathi CC. The Paraoxonase 1 arylesterase activity. Total oxidative stress. Nitric oxide and vitamin $\mathrm{C}$ levels in maternal serum, and their relation to birth weight of newborn. J Obstet Gynaecol India 2016;66:327-32.

24. Lawlor DA, Gaunt TR, Hinks LJ, Smith GD, Timpson N, Day INM, et al. The association of the PON-1 Q192R polymorphism with complications and outcomes of pregnancy: findings from the British Women's Heart and Health cohort study. Paediatr Perinat Epidemiol 2006;20:244-50.

25. Kumru S, Aydin S, Gursu MF, Ozcan Z. Changes of serum paraoxonase (an HDL-cholesterol-associated lipophilic antioxidant) and arylesterase activities in severe preeclamptic women. Eur J Obstet Gynecol Reprod Biol 2004;114:177-81. 